suicide has been given to medical students and student nurses. These changes in medical education can scarcely be reconciled with the Department of Health's recommendation ${ }^{6}{ }^{7}$ that all self-poisoned patients should see a psychiatrist and must strengthen the case for amending it. Lifting the restriction on clinical responsibility would enable physicians to decide for each of their self-poisoned patients whether a psychiatric opinion is necessary. Psychiatrists might teach junior staff to assess these patients and might concentrate more on improving the treatment and aftercare services in each district.

The royal colleges have the responsibility of ensuring that the doctors and nurses who customarily look after patients who have attempted suicide are given the necessary training for it. Eleven years after the Hill Report, ${ }^{7}$ the standing medical advisory committees should review arrangements for the treatment and aftercare of self-poisoned patients, and initiate a detailed study of the prevention of poisoning. Clinical medical schools might do more to improve the standard of medical education in this field. The best prospect of controlling the "epidemic" of self-poisoning seems likely to come from a preventive approach.

${ }^{1}$ Kennedył P, British Medical fournal, 1972, 4, 255.

2 Collier, J, Cummins, T A, and Hamilton, M, Fournal of the Royal College of Physicians, 1976, 10(4), 381.

${ }^{3}$ Blake, D R, and Mitchell, J R A, British Medical fournal, 1978, 1, 1032.

* Gardner, R, et al, British Medical fournal, 1978, 2, 1392.

5 British Medical Fournal, 1978, 2, 1246.

6 Ministry of Health, HM(61), 94.

${ }^{7}$ Ministry of Health, Scottish Home and Health Department. Central Health Services Council. Scottish Health Services Council, Hospital Treatment of Acute Poisoning. London, HMSO, 1968.

${ }^{8}$ Lawson, A A H, and Mitchell, I, British Medical fournal, 1972, 4, 153.

${ }^{9}$ Greer, S, and Bagley, C, British Medical fournal, 1971, 1, 310.

10 Gardner, R, et al, British Medical fournal, 1977, 2, 1567.

11 Newson-Smith, J G B, and Hirsch, S R, British fournal of Psychiatry, 1979, 134, 335.

12 Kessel, N, British Medical fournal, 1965, 2, 1265.

13 Stengel, E, Lancet, 1963, 1, 233.

14 Barraclough, B, et al, British Fournal of Psychiatry, 1974, 125, 355.

15 Holding, T A, et al, British fournal of Psychiatry, 1977, 130, 534.

16 Chowdhury, N, Hicks, R C, and Kreitman, N, Social Psychiatry, 1973, 8, 67 .

17 Gibbons, J S, et al, British Fournal of Psychiatry, 1978, 133, 111.

18 Hill, D, Psychiatry in Medicine; Retrospect and Prospect. London, Nuffield Provincial Hospitals Trust, Rock Carling Fellowship, 1969.

19 Barber, J H, et al, British Medical fournal, 1975, 2, 431.

\section{Feeding infants of low birth weight}

An ideal method of feeding an infant of low birth weight would produce the optimal rate of growth with minimal morbidity and mortality-and would cost little and make low demands on nursing time. The preterm infant is especially prone to malnutrition since he cannot suck, and providing enough calories may be difficult if he has the respiratory distress syndrome or recurrent apnoeic attacks.

Neonatal malnutrition is widely thought to have long-term effects-a belief based on the observation that animals kept undernourished at critical periods were found later to have reduced numbers of brain cells, though the glial but not the neuronal population was mainly affected. ${ }^{1}$ The human brain grows very quickly between 32 and 40 weeks of gestation, and the animal studies were thought to show trends which might be important for preterm infants. In animals the timing, duration, and severity of the insult determined the completeness of recovery. In man it is not known whether days, weeks, or months of malnutrition are needed to produce a permanent cerebral defect, but in an attempt to prevent any possible postnatal malnutrition the current fashion is for every effort to be made to mimic the intrauterine growth curve. This may be unnecessary ${ }^{2}$ and dangerous.

Yet, while the importance of weight gain is uncertain, morbidity, mortality, and cost can all be measured. The methods of feeding these infants are by the intragastric, transpyloric, or intravenous routes. Intermittent intragastric milk feeds may cause regurgitation and aspiration in some preterm infants during the first few days of life and especially in units with too few trained nursing staff. Another disadvantage is that these feeds may provoke a fall in arterial oxygen tension and a rise in heart rate and blood pressure. ${ }^{3}$ This is unlikely to occur when milk is given by continuous infusion into the stomach, ${ }^{4}$ or when the transpyloric route is used." A new generation of syringe pumps have made these methods technically easier. Many units have now had an opportunity to evaluate the transpyloric method, though passing the tube into the jejunum may be difficult: 72 hours had elapsed before it had passed in $80 \%$ of infants in one series, ${ }^{6}$ and $60^{\circ}{ }_{0}$ in another. ${ }^{7}$ Polyvinyl tubes become hard owing to loss of plasticiser, and this has been blamed for perforation of the gut. ${ }^{8}$ Though softer, silicone rubber tubes are more difficult to pass. Blind-ended tubes may cause a change of flora, and outbreaks of necrotising enterocolitis in intensive care units have coincided with the introduction of intrajejunal feeds. That risk may possibly be reduced by not using hyperosmolar feeds. ${ }^{5}$ The absorption of fat is reduced by half by using the transpyloric route, presumably because the gastric lipase is bypassed.

In the wake of the impressive increase in survival after intravenous feeding of glucose and amino-acids in infants undergoing surgery" this method was canvassed as the best way of feeding infants of low birth weight. Use of central venous catheters was, however, associated with a high incidence of infection and thrombosis, and most paediatricians began to use peripheral veins-despite the difficulties of having repeatedly to insert needles into tiny babies. Intravenous infusions of amino-acids and glucose have a protein-sparing effect, ${ }^{9}$ but the same problem arises as with babies who receive glucose and electrolyte infusions: too few calories are supplied. Adding intravenous lipid might help, but the free fatty acids may displace bilirubin from its protein receptors; this may preclude the use of an intravenous lipid during the first week of life. Intravenous lipid must be introduced gradually, the amount tolerated is variable, and three-quarters of the infants so treated have abnormal liver function tests. One study showed that $77 \%$ of infants receiving parenteral lipid infusions had appreciable deposition of fat in the intrapulmonary arteries with a persistence of a reduced lumen of the vessels. ${ }^{10}$

Some of these uncertainties may have been resolved by some more recent research. ${ }^{11} 12$ Infants given total parenteral nutrition were compared with a control group managed with conventional intragastric feeding. No differences were found in mortality between the two groups. In the study by $\mathrm{Yu}$ et $a^{12}$ six varieties of intravenous infusion were prepared daily by the pharmacy from raw materials costing over $£ 20$ for each baby in every 24 hours. The 34 babies were under the care of six consultant paediatricians, a professional officer, a technical officer, and presumably junior staff in numbers too embarrassing to mention. Long-term studies of neurological, intellectual, and behavioural development are being performed in these infants. Until these results are available-in about five years' time-there appears to be little or no justification 
for total parenteral feeding of infants of low birth weight unless the unit is carrying out a research study. The American Academy of Paediatrics gave similar advice about seven years ago $^{13}$ and reported it, ${ }^{14}$ and many will find it surprising that paediatricians continue to use this costly, dangerous form of treatment indiscriminately.

What should we do now? Depending on the medical and nursing staff available, each unit will have to decide whether to use the transpyloric route rather than the gastric route. Weary neonatal house physicians may not display the same enthusiasm for conquering the obstinacy of the pylorus as the research registrar: with any luck a better tube may soon become available.

${ }^{1}$ Dobbing, J, in Scientific Foundations of Paediatrics, ed J A Davis and J Dobbing, p 565. London, Heinemann, 1974.

2 Gaull, G E, Rassin, D K, and Raiha, N C R, Fournal of Pediatrics, 1977, 90, 507.

3 Wilkinson, A, and Yu, V Y H, Lancet, 1974, 1, 1083.

4 Valman, H B, Heath, C D, and Brown, R J K, British Medical fournal, $1972,3,547$.

Rhea, J W, and Kilby, J O, Pediatrics, 1970, 46, 36.

${ }^{6}$ Beddis, I, and McKenzie, S, Archives of Disease in Childhood, 1979, 54, 213.

' Cheek, J A, and Staub, G F, fournal of Pediatrics, 1973, 82, 955.

${ }^{8}$ Boros, S J, and Reynolds, J W, Fournal of Pediatrics, 1974, 85, 107.

${ }^{9}$ Heird, W C, et a, Fournal of Pediatrics, 1972, 80, 351.

1" Ballabriga, A, in Nutrition and Metabolism of the Fetus and Infant, ed H K A Isser, p 402. The Hague, Boston, London, Martinus Nijhoff, 1979.

${ }^{11}$ Gunn, T, et al, fournal of Pediatrics, 1978, 92, 606.

12 Yu, V Y H, et al, Archives of Disease in Childhood, 1979, 54, 653.

${ }^{13}$ American Academy of Pediatrics Committee on Nutrition, Pediatrics, 1972 49, 776.

14 American Academy of Pediatrics Committee on Nutrition, Pediatrics, 1977, 60, 519.

\section{Analgesia and the acute abdomen}

We look back aghast at cruelties inflicted on patients by our predecessors, and there is no reason to suppose that our successors will not be equally appalled by some of the things we do now. But perhaps there is one contemporary unkindness which we could abandon ourselves.

The thought is prompted by the appearance of a revised edition of Zachary Cope's book on the acute abdomen, whose opening chapter contains the sentence": "If morphine be given, it is possible for a patient to die happy in the belief that he is on the road to recovery, and in some cases the medical attendant may for a time be induced to share the delusive hope." This striking admonition (first written in 1921) has become something of a tradition, in the sense that many apprentice surgeons believe it without having actually been taught it. As a consequence, a patient with renal colic or a perforated peptic ulcer may commonly be seen by four medical attendants-general practitioner, casualty doctor (perhaps an experienced consultant), houseman, and trainee surgeon-before any analgesia is sanctioned, on the questionable ground that the last must see the clinical picture at its most florid in order to be able to make a diagnosis.

The advice to withhold analgesia until a firm diagnosis had been made was undoubtedly valid 60 years ago, when surgery, if indicated, had to be performed under primitive anaesthesia, without any of the supportive and restorative measures which we take so much for granted today: readily available blood transfusion, correction of electrolyte and fluid imbalance, antibiotics, intensive care, and even gastric aspiration to prevent vomiting and inhalation. In those circumstances the primary condition's progress clearly had to be halted as soon as possible, before its secondary manifestationssuch as shock and dehydration-became too advanced for the patient to recover spontaneously. That is why Cope was intolerant of anything, including analgesia, which might have delayed the decision to operate by even a few hours.

But we order things differently now. Except when there is torrential haemorrhage we adopt a more leisurely and methodical approach. We spend time correcting the secondary manifestations before operating to deal with the primary disease. We use this time also to do investigations and make observations which may help diagnosis; indeed, the speed and degree of response to resuscitation are themselves of significance, and relief of pain and neurogenic shock is an important part of resuscitation. Why, then, should the first doctor called to the patient be debarred from giving real first-aid in the form of analgesia-preferably intravenously, titrated against the pain? Young surgeons can surely learn to diagnose an acute abdomen in a sedated patient; they might find it easier than they think.

In any case, not all writers on the subject feel so strongly as Cope, and some actually disagree with him. Shepherd ${ }^{2}$ and Bailey ${ }^{3}$ - though the latter is more concerned with treatment than diagnosis-make no mention of the matter. Jones ${ }^{4}$ recommends sedation as an aid to diagnosis in children. Dunphy, who says that analgesia should be given "without hesitation," "' and Angell ${ }^{6}$ also agree that it makes signs easier to evaluate, in that tenderness and rigidity may become localised and masses become palpable. And surely a patient out of his mind with pain is not in a state to give a liable history.

Urgent relief of severe pain is good treatment, humane, and unlikely-to say the least-to do harm nowadays by delaying diagnosis. Need we wait for our successors to criticise us? Could we not institute a new tradition ourselves-starting now?

1 Silen, W, revised by, Cope's Early Diagnosis of the Acute Abdomen, 15th edn, p 5, New York, Oxford University Press, 1979.

2 Shepherd, J A, Surgery of the Acute Abdomen, 2nd edn. Edinburgh, Livingstone, 1968.

${ }^{3}$ Dudley, H A F (ed), Hamilton Bailey's Emergency Surgery, 10th edn, Bristol, John Wright, 1977.

4 Jones, P F, Emergency Abdominal Surgery, p 138. Oxford, Blackwell Scientific, 1974.

${ }^{5}$ Dunphy, T E, and Way, L W, Current Surgical Diagnosis and Treatment, 3rd edn, p 446. Los Altos, California, Lange Medical, 1977.

${ }^{6}$ Angell, J C, The Acute Abdomen for the Man on the Spot, 3rd edn, p 42. Tunbridge Wells, Pitman, 1978.

\section{Dissection of the aorta}

Twenty-one years ago Hirst $e t \mathrm{al}^{1}$ analysed a collection of over 500 cases of dissection of the aorta. The death rate was high. More than half the patients were dead by the fifth day of the disease and $91 \%$ by six months, the remaining $9 \%$ surviving for up to nine years.

This high death rate was not surprising, since at that time surgical treatment consisted of fenestration, aimed at decompressing the dissected sac. Results were poor in the acute stage, but there were more successes when the condition was chronic. In 1965, however, De Bakey's group, ${ }^{2}$ using a direct 